\title{
Acting collectively to develop midscale food value chains
}

\author{
Larry Lev ${ }^{\mathrm{a}}$ and G. W. Stevenson ${ }^{\mathrm{b}}$
}

Submitted 15 February 2011 / Accepted 2 May 2011 / Published online 2 August 2011

Citation: Lev, L., \& Stevenson, G. W. (2011). Acting collectively to develop midscale food value chains. Journal of Agriculture, Food Systems, and Community Development, 1(4), 119-128. http://dx.doi.org/10.5304/jafscd.2011.014.014

Copyright (C) 2011 by New Leaf Associates, Inc.

\begin{abstract}
This paper uses case studies of four innovative U.S. midscale food value chains to provide models of how midsized farms and ranches and associated processing, distribution, and retail businesses can prosper by acting collectively to construct a "third tier" in the U.S. agri-food system. Specifically we consider the importance of acting collectively at three distinct levels: horizontally among producers, vertically within food value chains, and horizontally across food value chains. These midscale food value chains represent strategic alliances among midsized farms and other agri-food enterprises that operate at regional levels, handle significant volumes of high-quality, differentiated food products, and distribute profit margins equitably among the strategic partners. From a market perspective, the key advantage of these food value chains is their ability to provide these high-quality, differentiated

\footnotetext{
a Corresponding author: Larry Lev, Department of Agricultural and Resource Economics, Oregon State University, Corvallis, OR 97331-3601 USA; Larry.lev@,oregonstate.edu

${ }^{b}$ G. W. Stevenson, Center for Integrated Agricultural Systems, University of Wisconsin, Madison, WI 53706-1215 USA
}

products that are not available through the mainstream commodity market.

\section{Keywords}

community of practice, differentiated products, midsized farms, regional, strategic partnerships, supply chains, sustainability, value chains

\section{Introduction and Background}

Historically, midsized, "farming occupation" farms have been the backbone of the U.S. agricultural sector. In recent decades, however, farms in this size range have been severely challenged because they are often too small individually to compete successfully in global agricultural commodity markets, while also being too large and/or poorly positioned to directly market their products to local consumers. Yet many observers believe these midsized farms remain important for their environmental stewardship, their contributions to community vitality, and the role they play in maintaining a diverse, resilient, and more sustainable structure of agriculture (Stevenson \& Pirog, 2008).

Figure 1 depicts the relationship between farm size and production and marketing opportunities. As 
indicated by $\mathrm{X}$ in the upper left cell, small farms have their greatest chances for success by producing and selling differentiated products in local markets through direct markets and short supply chains. ${ }^{1}$ In contrast, large farms have a competitive advantage in the low margin/high volume global markets for farm commodities (the $\mathbf{X}$ in the lower right cell). These products move through efficiency-based supply chains. Many midsized farms have traditionally supplied these commodity markets. This paper focuses on midsized farms that are trying to make the transition from the "Troubled Zone" of competing largely unsuccessfully with large farms, to the "Opportunity Zone" of producing and marketing differentiated products. These farm products travel from producers to consumers via values-based supply chains, or what we refer to as "value chains" in this paper. We draw on four detailed case studies to examine how mutually supporting social relations, what we term here "acting collectively," must functions at three distinct levels - horizontally among producers, vertically within food value chains, and horizontally across food value chains - in order for this transition to succeed.

The research team prepared in-depth case studies based on a sequence of interviews of key actors, a review of essential documents, a formalized feedback process to revise the written draft cases, and then a set of interactions during two multiday workshops with the case study principals. This last step of the case study process, what is termed "learning across value chains," follows a community of practice approach that is discussed and

\footnotetext{
${ }^{1}$ Some farms of all sizes sell through each market type. This figure focuses on the farm size/market type pairings that are most successful.
}

documented in section 3 of this paper. During the workshops, the case principals and the research team exchanged ideas and insights and brainstormed alternatives.

The four midscale food value chains we studied vary in their organizational structure, location in the country, types of products handled, and volume of sales. They all can be characterized as strategic alliances among primarily midsized farms ${ }^{2}$ and other agri-food enterprises that operate at regional levels, handle significant volumes of highquality, differentiated food products, and distribute profit margins equitably among the strategic partners. In addition, the products possess unique stories that identify where the food comes from and how it is produced, and they reach the marketplace via transparent supply chains built on equitable business relationships that seek to gain consumer trust and support. Within the alliances, the farmers function as strategic partners, rather than

\footnotetext{
2 Most, but not all, the farms have gross sales below the US $\$ 500,000$ level, which is commonly used as the upper limit of midsized farms. See the discussion in Stevenson et al. in this volume.
} 
as interchangeable input suppliers. They receive prices based on reasonable calculations of their production and transaction costs, longer term contracts than standard for their products, and are able to control their own brand identities as far up the value chain as they choose.

The cases vary significantly in the number of member farms in each strategic alliance (under 50 to over 1,500), value of sales (less than US $\$ 1,000,000$ to over US\$500,000,000), and style of organization (two are cooperatives and two are not). But they also share much in common and provide significant insights to others. The strategies that they follow and that we analyzed and evaluated are grounded in solid business theories for developing competitive enterprises that produce and market products that have "unique and superior value" (Dyer, 2000; Kumar, 1996; Peterson, 2002; Porter, 1998; Porter \& Kramer, 2011). Yet they dynamically employ both the power of collective action and collaborative business partnerships (Handfield \& Nichols, 2002) to create "fair trade" business models that distribute value equitably among business partners in both international and domestic markets (Jaffee, Kloppenburg, \& Monroy, 2004).

The four cases are 3 :

- Country Natural Beef: A 120-member beef rancher cooperative in the northwestern United States;

- CROPP/Organic Valley: A 1,650member, multiregional farmer cooperative marketing organic dairy, eggs, vegetables, and other products;

- Shepherd's Grain: A 35-farmer limited liability corporation marketing sustainably grown and functionally specified wheat flour in the northwestern United States;

- Red Tomato: A nonprofit, domestic fairtrade business that provides marketing

${ }^{3}$ Links to the complete case studies and the individual $\underline{\text { websites }}$ are provided following the reference section. services to 35 fruit and vegetable farmers in the northeastern United States. ${ }^{4}$

Selected cross-case findings highlight the importance of:

- Developing pricing systems based on two principles: (1) supply management and stable prices, and (2) cost of production-based pricing;

- Communicating the deeper, more complex values that differentiate these value chains from mainstream supply chains, including land stewardship, fair returns to all value chain participants, and maintenance of diverse farm and ranch structures;

- Screening of potential new producermembers by existing members in terms of both production capabilities and integrity;

- Employing farmers and ranchers as business representatives, storytellers, and listeners.

The common elements across these findings are the need for accurate information, the importance of open communication, and the need for shared values. In the next three sections, we examine how this happens at three levels.

\section{Acting Collectively at the Farm Level}

Each of the value chains developed in response to the challenge posed in figure 1 is working collectively to earn sustainable price premiums in the marketplace. This sometimes requires passing up the highest possible prices in the short term in order to protect long-term relationships and income.

Country Natural Beef members are very explicit in describing this collective action as a means to an end: they act collectively so that the individual

\footnotetext{
${ }^{4}$ Although Red Tomato is a dual-purpose organization that also consults on regional food system development, in this paper only the marketing portion of the business will be considered.
} 
member ranches are able to maintain "every possible bit of independence." In contrast to most cooperative organizations, Country Natural Beef member ranches do not invest equity in the organization, so there is nothing about the organization that can be bought or sold. While many competing natural beef brands have changed ownership in the last decade, this cannot happen for Country Natural Beef. The money earned from the sale of cattle flows directly to individual ranching families, and the cooperative prides itself on maintaining extremely low overhead and administrative costs (just over 4\%). Country Natural Beef hires no staff, instead employing members who act as independent consultants and "internal partners" to handle key functions that include production planning, sales, and accounting.

Working collectively requires significant investments in building relationships among members and an acceptance of group decisions. Country Natural Beef requires member ranches to participate in semiannual business meetings. At these meetings, all major decisions are discussed until a consensus is reached. As is true for the other producer groups, all Country Natural Beef ranches must follow strict standards on bow to produce and agree to group decisions on when and how much to produce. Each ranch also commits to spending two weekends a year in the retail marketplace interacting with both value chain partners and end consumers. One remarkable outcome of these procedures is that all members display an impressive command of the business philosophy and practices. Acting collectively means seeking active participation from within the farm or ranch households. Each of these case study organizations is strongly committed to the full participation of women and men across all aspects of the organization.

Shepherd's Grain very explicitly modeled itself after Country Natural Beef and adopted many of its practices, including a commitment to very low overhead, dependence on internal partners rather than hired staff, and use of facilitated annual meeting practices to examine strategic decisions. But for tax and flexibility purposes, Shepherd's
Grain was organized as a limited liability corporation rather than a cooperative so the individual farmers who grow the wheat do not have the same direct decision-making authority that the Country Natural Beef ranches do. At this point, Shepherd's Grain member farms sell less than $25 \%$ of their production through the collective and sell the rest on the generic commodity market.

Organic Valley, a much larger organization, contrasts in several ways with Country Natural Beef and Shepherd's Grain. The member farms are required to make an equity investment equal to $5.5 \%$ of the farm's annual sales, and the cooperative employs a full staff to administer the business. No annual meetings are held for the general membership. Nevertheless, Organic Valley operates so that member net revenues are maximized, rather than cooperative net revenues.

Deciding to reduce member incomes is often the most difficult collective decision. In 2008 as the organic milk market weakened, Organic Valley moved aggressively by both cutting producer prices and instituting supply control measures (that is, decreasing deliveries from all member dairies). These two efforts succeeded in minimizing the overall impact on all member farms and demonstrated the power of collective action (Barham, 2010). The other organizations share both the focus on the long run and the philosophy of distributing the rewards and pain equitably among all members.

Organic Valley places a priority on preparing for the future by providing both an exit strategy for current farmers and a means of entry for the next generation of farmers. As Chief Financial Officer Mike Bedessem puts it, "We know what our job is: It's to get to the point where our farmers have a choice - they can farm, they can retire, they can sell to the kids. That's the exit strategy for our current farmers - it's a future for their kids." Similarly, Country Natural Beef founder Connie Hatfield notes, "My definition of sustainability is when more than 25 kids below the age of five require daycare at our semiannual meetings." 
The three farmer organizations recognize that recruiting new members represents an important challenge. Since they focus on member returns, they all follow the strategy of adding members only when demand for their products clearly exceeds supply. This is particularly important because, as in the Organic Valley example, they generally choose to treat new members on an equal footing with old members and therefore unexpected reductions in demand reduce everyone's returns, not just those of the new members. ${ }^{5}$ The organizations indicate a preference for members who are comfortable with a strategy of "getting rich slow." This means that they prefer members who are patient and will remain loyal to the organization even when market conditions are such that individual producers would benefit from being outside the constraints of long-term value chain agreements. This occurs when mainstream market prices rise quickly and steeply and has caused membership issues for all of the organizations including, in extreme circumstances, producers who choose to quit because they cannot or will not pass up the short-term gains.

As noted earlier, Red Tomato is a nonprofit rather than a farmer-run organization. Still the mission of the organization ensures that it focuses on providing long-term benefits to the farms that market through Red Tomato. In common with the other three organizations, it faces the challenge of selecting the "right" farms. Red Tomato's approach to recruitment is typical. It seeks farms that meet a set of criteria: they produce sufficient volume and variety, have adequate storage, refrigeration, packing, and trucking capacity, provide a geographic fit with the rest of the business, and have leaders whose temperaments fit the culture of Red Tomato. According to Michael Rozyne, this generally means that the farms are neither "so large" that Red Tomato only handles a smart part of their business, nor "so small" that the farm output provides only a small contribution to what is marketed. As is true for the other organizations,

\footnotetext{
${ }^{5}$ Three of the four organizations require a trial membership period, but it is intended to make sure the farm or ranch is a good fit, not to allow for a response to poor markets.
}

Red Tomato relies on existing growers to nominate new growers as a key means of ensuring future product quality and business tranquility. Organic Valley requires that new members and employees successfully complete an extensive education and socialization process. The cooperative credits these requirements with keeping the organization on mission during periods of rapid growth in sales and personnel.

\section{Acting Collectively in the Value Chain}

In contrast to direct marketers and to large vertically integrated firms, the producers in these value chains depend on cooperation with many other enterprises to get their products to end consumers. The distribution of rewards across the value chain becomes a key element that must be negotiated. Karl Kupers of Shepherd's Grain defines the idealized value chain they all seek to form as a supply chain "where greed does not exist" and within which all the participants "take value."

On a more practical level, however, the development of a pricing philosophy is central to all four businesses. For Shepherd's Grain, the starting point was to unlink the price received by Shepherd's Grain producers from commodity wheat prices so their farmers could receive a more stable and equitable return. Shepherd's Grain decided to set stable, six-month-long prices based on cost of production plus a reasonable rate of return, rather than to charge a premium above commodity wheat prices. Cost of production is calculated as the sum of on-farm production expenses, transportation costs, Shepherd's Grain administrative fees, and milling fees. Red Tomato, with the business mission to be a "food decommodifier" so that the high-quality products it markets for farmers earn suitable rewards, uses a less quantitative approach. The Red Tomato pricing philosophy can be traced back to the fair trade model, setting it apart from other produce distributors in the region. ${ }^{6}$ Red Tomato refers to it as a dignity pricing model. Prices are based on a combination of growers' perceptions of their own pro-

\footnotetext{
${ }^{6}$ See, for example, the description of the model used by Equal Exchange at http://www.equalexchange.coop/story
} 
duction costs, their experiences in the market, and their sense of what is fair. It works like this: Red Tomato traders ascertain from growers the following price points: (a) the average price recently received for a given product; (b) the price they want through the Red Tomato brokerage; and (c) the lowest price they will accept with dignity. Armed with this information, Red Tomato traders seek to get the highest reasonable price from a given buyer.

Organic Valley focused from the start on selling its products through multistage value chains rather than through direct marketing channels. It credits much of its early success to contracting out the key parts of its processing and distribution systems rather than sinking money into bricks and mortar and performing these supply chain functions itself. It owns only a single processing facility and has virtually all the Organic Valley milk processed on contract with dairy manufacturing plants located close to the regionally organized milk pools. In most instances these are independent, familyowned processors. It also contracts for transportation of both its raw milk and finished products, generally by independent trucking companies, many of which are smaller, family-owned firms. In contrast to the decision not to build physical infrastructure, the cooperative has made significant internal investments in supply chain logistics, and its leaders view excellence in this area as critical to its success. In fact, Organic Valley has spun off its logistics arm as a full subsidiary of the main business.

Country Natural Beef develops business partnerships based on the Japanese concept of "Shin Rai," or mutual support and mutual reward. The cooperative works with business partners who provide complementary services and expertise, and share basic values such as humane animal treatment and land stewardship. These partners maintain Country Natural Beef's identity on its products through to the final consumers. Retail partners include Whole Foods, New Seasons Market, Burgerville, and Bon Appétit Management Company. The cooperative faces a significant challenge in balancing its mix of retail partners to ensure sale of the entire animal, rather than just the most sought-after cuts.

Shepherd's Grain uses strategic value chain partners to replace the capital and expertise that otherwise would be required to handle grain milling and distribution. These partners provided early assistance in assessing wheat varieties and flour quality, and in locating customers. Shepherd's Grain flours are milled at the Archer Daniels Midland (ADM) mill in Spokane, Washington, the only significantly sized flour mill in the region and thus the only real processing option in close proximity to the farms. While ADM is a massive multinational firm, Shepherd's Grain has developed a close relationship with this regional mill. The partnership with ADM provides several advantages to Shepherd's Grain, including strict assurances that their products remain separate, excellent flour quality, ${ }^{7}$ marketplace credibility, and a safety net, as ADM assumes ownership of the wheat once it is delivered to the mill. Shepherd's Grain works with multiple distributors such as Food Service of America that act as sales agents for their products. Nearly all sales are direct wholesale, which means that Shepherd's Grain depends on its value chain partners and customers to preserve its brand identity in the marketplace. Strategies for maintaining brand identity with the assistance of its customers include, for example, a photo of Shepherd's Grain farmers on the Hot Lips Pizza website and farmer visits at Bon Appétit cafés. More recently, Shepherd's Grain has begun co-branding retail flour products with a small regional flour company. In all of this, Shepherd's Grain seeks out customers and business relationships that value the quality and story behind their products. In 2008, they parted ways with a customer who was only interested in price and not a strategic values-based relationship. Says Karl Kupers, a founder, "Maintaining our story and identity are important to us...if that's not important to the 'big guys,' then they can go somewhere else."

The Red Tomato that exists currently grew out of

\footnotetext{
${ }^{7}$ The mill is less automated than most American facilities and thus allows for the wheat to be milled to more precise and diverse standards.
} 
unsuccessful attempts the organization made to operate on a broader geographic scale with the entire physical infrastructure needed to create an alternative food distribution system. In 2003 the organization got rid of the trucks and coolers and kept the customers and farmers. In other words, Red Tomato became a value chain coordinator rather than a supply chain operator. The company's ability to coordinate depends on establishing effective, strategic partnerships that provide needed expertise and capacity. From the perspective of the firm's retail business clients, Red Tomato creates value by providing the logistical support necessary for aggregation and distribution, so that these retailers can purchase a broad variety of products from a single source. Farmers choose to delegate marketing responsibilities to Red Tomato so that they (the farmers) can focus on production.

For distribution services, Red Tomato relies on both its farmers and three independent trucking companies. It has formed retail and food service partnerships with a wide range of businesses ranging from large retailers, such as Whole Foods and Trader Joe's, to much smaller, independent companies. Part of Red Tomato's mission is to make its exceptional products accessible to consumers where they shop and eat - supermarkets, natural grocery chains, co-ops, independent grocery stores, institutions, and restaurants with a commitment to regional products. According to Red Tomato's Michael Rozyne, the two key questions that potential partners must answer are "Is Red Tomato important to you?" and "Do your customers want our stuff?" The goal is to work toward long-term business relationships, but there is a recognition that partnerships should begin with a two- or three-year trial period.

While all of the value chains talk about trust and relationships, many also have moved toward establishing formal written contracts with their partners. Over time, this sharing and transparency generate trust. Trust is pointed to as a pivotal component in successful value chains by virtually all observers of these interorganizational alliances. It is important that trust in value chain participants be based on not only personal relationships but on organiza- tional procedures. ${ }^{8}$ In other words, trust is based in the fairness and predictability of the procedures and agreements among strategic partners. Policies are consistent and stable over time, and do not change with new management or personnel. Country Natural Beef spent over two years negotiating an agreement with its primary retail partner that rests on interorganizational commitments, and not on interpersonal relationships.

Consumers are the final link in these value chains. The USDA "Know Your Farmer/Know Your Food" initiative and retailers ranging from Whole Foods to Wal-Mart all seek to increase the recognition and visibility of individual producers. ${ }^{9}$ This focus on individual producers provides a challenge for these four value chains, since one of the key reasons for their development was that, for reasons of scale and geography, direct sales from producers to consumers were impractical. In the United Kingdom, Marsden and his colleagues (Marsden, Banks, \& Bristow, 2000, p. 425) describe three alternative supply chains types that provide opportunities for gaining consumer loyalty and support:

1. Face-to-face: Personal interactions such as consumer supported agriculture, farmers' markets and farm stands;

2. Spatial proximity: Supermarkets, restaurants, and institutions highlighting local/regional products; and

3. Spatially extended: Product and producer characteristics are transmitted to consumers outside the region. ${ }^{10}$

These midscale value chains try to benefit from

\footnotetext{
${ }^{8}$ For an expanded discussion of interorganizational trust, see Stevenson and Pirog (2008).

${ }^{9}$ See for example: http://walmartstores.com/pressroom/news/8414.aspx, http://www.wholefoodsmarket.com/products/locallygrown/, and http://www.usda.gov/wps/portal/usda/knowyourfarmer? navid=KNOWYOURFARMER

${ }^{10}$ This topic is also discussed in Clancy and Ruhf, 2010.
} 
both the spatial proximity and the spatially extended alternatives. In both alternatives, the organizations in these case studies must wrestle with whether consumers will form a relationship with the overall brand or whether consumers prefer and perhaps even require a bond with individual producers. The results to date have led the four organizations to proceed on both fronts by trying to build a brand identity that means something to consumers and by identifying ways to highlight linkages back to individual growers.

Of the four value chains, it is the non-farmer operated organization, Red Tomato, that provides the most concrete links between producers and consumers through labeling and storytelling efforts. Because the products that Red Tomato handles can be segregated by grower, this proves to be fairly easily managed. Additionally, Red Tomato will soon experiment with Internet-based social networking approaches to connecting consumers with its farmers and its brand (M. Rozyne, personal communication, 10/28/2011).

The other three organizations all handle products that are aggregated for processing. So while all three feature the producers whenever possible, they find it much more difficult to preserve the individual farm identity all the way through to the consumer. Shepherd's Grain's "Find the Farmer" website does allow the supermarket consumer to enter a code from the flour sack and determine the set of farms that had flour milled that day. The Organic Valley website provides information on the farms nearest to the consumer's location. So both organizations have made some progress on filling this gap. Country Natural Beef has also begun to explore the changes it would need to make to provide a more direct consumer/producer link. Still, none of these organizations will ever equal the intimacy of contact achieved in farmdirect channels.

\section{Learning Across Value Chains}

In the course of conducting the case study research and disseminating the results, the research team began to recognize the learning that took place when the case study principals read the different cases and interacted with each other during project workshops. Despite focusing on different crops and being organized in different ways, they quickly formed a community of practice $(\mathrm{CoP})$ and readily exchanged insights and suggestions. Selected examples include:

- The interest sparked by the "dignity price" concept or model that Red Tomato has introduced as a means of establishing fair compensation for growers and other approaches for establishing prices in value chains;

- Descriptions of what the end consumers in their value chains care about the most;

- Comparisons of strategies for dealing with mainstream food distributors;

- Intense and valuable exchanges among case study principals regarding ideas for responding to the 2008 economic slowdown internally and in relations with value chain partners;

- Discussions of how to best communicate considerations of environmental ethics across value chains; and

- Recognition of the key factors that contribute to the resilience of successful value chains.

As researchers, we now focus much more on the learning across value chains because it represents an important extension of the community of practice concept. The original CoP literature focused on facilitating social learning within individual corporations (Wenger, McDermott, \& Snyder, 2002). The second strand of the CoP literature focused on facilitating virtual learning communities and defined a major role for the public sector (Sobrero, 2008; Sobrero \& Craycraft, 2008). Our focus is on the unique opportunities and challenges of the detailed information exchanges among groups such as these case study principals who are not in the same firm and have their own learning 
agenda rather than one set by the public sector. We are experimenting with different ways of exchanging information and will document through observations and questionnaires the costs and benefits that accrue to the participants. Finally we will assess the long-term sustainability of the $\mathrm{CoP}$ and the transferability of this approach — and the lessons learned by the $\mathrm{CoP}$ - to other participants.

\section{Final Thoughts}

Taken as a whole, the four case studies demonstrate that farms of the middle have both the capacity and the flexibility to work collectively with each other and with their value chain partners to create midscale food value chains that successfully respond to expanding market opportunities. They also value the ability to learn from each other. As they move forward they must further develop these key areas: (1) adapting and protecting value chain pricing principles, especially resilience in times of economic stress; (2) strengthening relationships with strategic business partners; (3) strengthening communication with consumers; (4) deepening product differentiation; (5) achieving greater efficiencies; and (6) addressing organizational positioning, maturation, and succession. Additional work must also address the sorely lacking policy instruments and funding, both public and private that will increase the viability of these small and medium-sized farms and their collectively created value chain partnerships within agriculture's "third tier."

\section{Acknowledgements}

The research is supported through funding from the following two USDA/NRI/NIFA grants: \#2006-55618-17014 and \#2010-85211-20577.

\section{References}

Barham, B. (2010). Price stability in an era of rollercoaster rides. Status of Wisconsin Agriculture 2010. Department of Agricultural and Applied Economics, University of Wisconsin-Madison and Cooperative Extension, 44-47.

Clancy, K., \& Ruhf, K. (2010). Is local enough? Some arguments for regional food systems. Choices, 25(1). Retrieved from http://www.choicesmagazine.org/
Dyer, J. (2000). Collaborative advantage: Winning through extended enterprise supplier networks. New York, NY: Oxford University Press.

Handfield, R., \& Nichols Jr., E. (2002). Supply chain redesign: Transforming supply chains into integrated value systems. Upper Saddle River, NJ: Prentice Hall.

Jaffee, D., Kloppenburg, J. R., \& Monroy, M. B. (2004). Bringing home the "moral charge": Fair trade within the North and within the South. Rural Sociology, 69(2), 169-196.

Kumar, N. (1996). The power of trust in manufacturerretail relationships. Harvard Business Review, 74(6), 92-107.

Lyson, T., Stevenson, G., \& Welsh, R. (Eds.). (2008). Food and the mid-level farm. Cambridge, MA: The MIT Press.

Marsden, T., Banks, J., \& Bristow, G. (2000, October). Food supply chain approaches: Exploring their role in rural development. Sociologia Ruralis 40(4), 424 438. http://dx.doi.org/10.1111/1467-9523.00158

Peterson, H. C. (2002). The "learning" supply chain: Pipeline or pipedream? American Journal of Agricultural Economics, 84, 1329-1336. http://dx.doi.org/10.1111/1467-8276.00398

Porter, M. (1998). Competitive advantage: Creating and sustaining superior performance. New York, NY: The Free Press.

Porter, M., \& Kramer, M. (2011, January-February). Creating shared value. Harvard Business Review, Reprint R1101C.

Sobrero, P. (2008, August). Essential components for successful virtual learning communities. Journal of Extension, 46(4). Retrieved from http://www.joe.org

Sobrero, P. M., \& Craycraft, C. (2008, October). Virtual communities of practice: A $21^{\text {st }}$ century method for learning, programming, and developing professionally. Journal of Extension, 46(5). Retrieved from http://www.joe.org

Stevenson, G. W., \& Pirog, R. (2008). Values-based supply chains: Strategies for agrifood enterprises of the middle. In T. Lyson, G. Stevenson, \& R. Welsh (Eds.). Food and the mid-level farm, 119-143. Cambridge, MA: The MIT Press.

Wenger, E., McDermott, R., \& Snyder, W. M. (2002). Cultivating communities of practice. Boston, MA: Harvard Business School Press. 
The four case study reports and related documents are available at the Agriculture of the Middle website: http://www.agofthemiddle.org/

Websites of the four organizations:

- Country Natural Beef: http://www.countrynaturalbeef.com/

- Organic Valley: http://www.organicvalley.coop/

- Red Tomato: http://www.redtomato.org/index.php

- Shepherd's Grain: http://www.shepherdsgrain.com/ 